PHYSICAL AND TECHNICAL ENERGY PROBLEMS

\title{
ANALYSIS OF COMPETITIVENESS AND SUPPORT INSTRUMENTS FOR HEAT AND ELECTRICITY PRODUCTION FROM WOOD BIOMASS IN LATVIA
}

\author{
G. Klavs, I. Kudrenickis, A. Kundzina \\ Laboratory of Energy System Analyses and Optimisation, \\ Institute of Physical Energetics, \\ 21 Aizkraukles Str., Riga, LV-1006, LATVIA \\ e-mail: energy@edi.lv
}

\begin{abstract}
Utilisation of renewable energy sources is one of the key factors in a search for efficient ways of reducing the emissions of greenhouse gases and improving the energy supply security. So far, the district heating supply in Latvia has been based on natural gas, with the wood fuel playing a minor role; the same is true for decentralised combined heat-power (CHP) production. The paper describes a method for evaluation of the economic feasibility of heat and electricity production from wood biomass under the competition between different fuel types and taking into account the electricity market. For the simulation, a cost estimation model is applied. The results demonstrate that wood biomass can successfully be utilised for competitive heat production by boiler houses, while for electricity production by CHP utilities it cannot compete on the market (even despite the low prices on wood biomass fuel) unless particular financial support instruments are applied. The authors evaluate the necessary support level and the impact of two main support instruments - the investment subsidies and the feed-in tariff - on the economic viability of wood-fuelled CHP plants, and show that the feed-in tariff could be considered as an instrument strongly affecting the competitiveness of such type CHP. Regarding the feed-in tariff determination, a compromise should be found between the economy-dictated requirement to develop CHP projects concerning capacities above $5 \mathrm{MW}_{\mathrm{el}}-$ on the one hand, and the relatively small heat loads in many Latvian towns - on the other.

Key words: energy production price, district heating system, wood biomass fuel, combined heat/ power production, investment subsidies, feed-in tariff.
\end{abstract}

\section{INTRODUCTION}

Europe 2020 Strategy - as that of EU's growth for the current decade - has set objectives for the EU energy-climate policy, which is translated into national targets adopted by each of the member states. The quantitative targets set in Latvia for 2020 are to achieve the renewable energy sources (RES) share of $40 \%$ in the gross final consumption, the primary energy saving of 0.67 Mtoe, and the limitations of $+17 \%$ (as compared with 2005) for greenhouse gas (GHG) emissions in the sectors not covered by the Emissions Trading System [1].

Taking into account the current situation in Latvia, these targets are ambitious, so they are to be assessed from the viewpoint of possible problematic

N o t e. In the article, the national currency of Latvia is used. The currency exchange rate of Latvijas Banka is $1 \mathrm{EUR}=0.702804 \mathrm{LVL}$. 
situations and need a roadmap for achieving them. The paper is devoted to the first of these targets - to increase the use of RES and, in this context, to analyse the preconditions for expansion of wood biomass utilisation for district heating systems (DHS) and electricity production. In 2010, the total final energy consumption in Latvia was 181.5 PJ [2]. Figure 1 shows the corresponding fuel consumption shares: the highest - for heating (47\%), the next largest consumption - transport fuels $(28 \%)$; the DHS share is $13 \%$, while the electricity consumption makes up only $12 \%$ of the total final energy consumption.

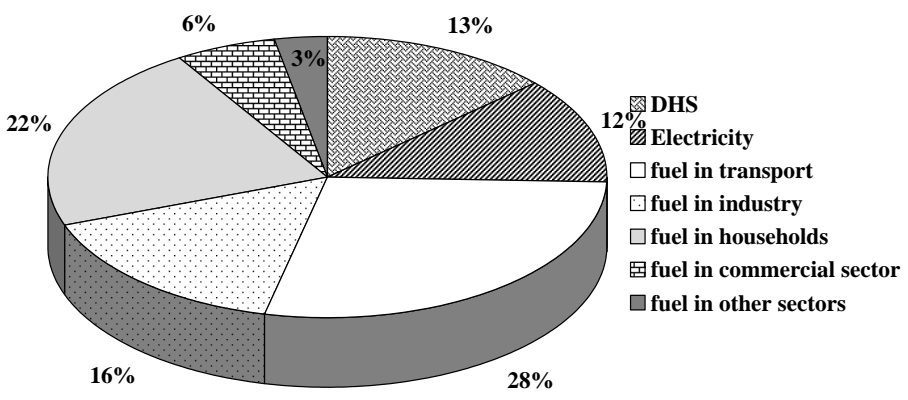

Fig. 1. Final energy consumption by type of energy resources, 2010.

In 2010 wood biomass contributed $\sim 25.6 \%$ of the total primary energy supply in Latvia [2], with essentially different share of biomass utilisation in various sectors. Wood is the dominant fuel $(78 \%)$ in the household sector. At the same time, the share of wood fuel in the DHS is significantly lower - only $16 \%$. What is important, its most proportion $(\sim 85 \%)$ is used for the heat production at boiler houses (BHs), and only a small part is utilised at the combined heat-power (CHP) plants. The share of RES in the final electrical energy consumption is $48 \%$, with the greatest part (97\%) provided by large-scale hydroelectric power stations (see Fig. 2).

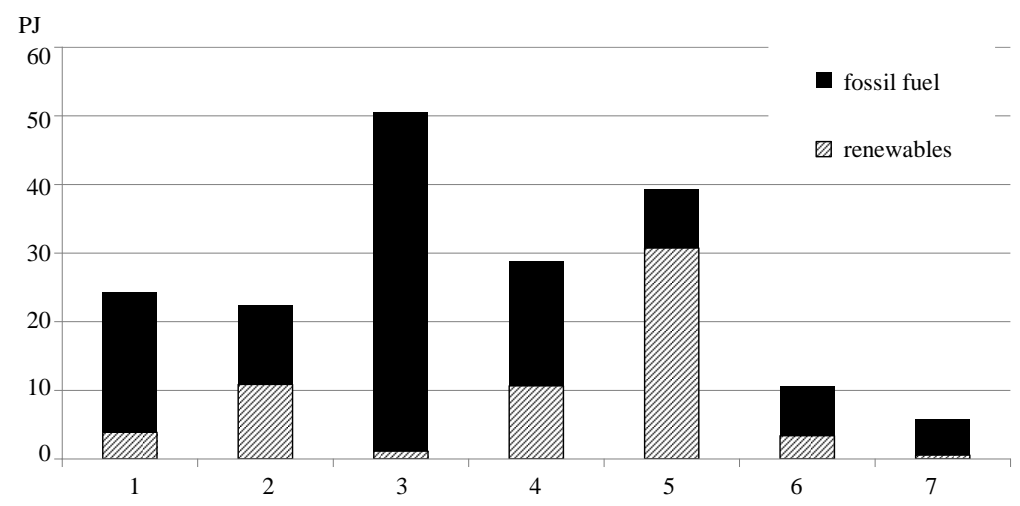

Fig. 2. Use of RES and fossil fuel for different types of energy and consumers, 2010 [2]: 1 - DHS; 2 - electricity; 3 - transport; 4 - industry; 5 - households; 6 - commercial sector; 7 - other sectors.

In 2009, the RES share (calculated in accordance with Directive 2009/28/EC methodology) accounted for $34.3 \%$ of the total final energy consumption, which was the second highest in the EU after Sweden (47.3\%) [3]. 
The future deployment of RES utilities in Latvia is closely related to the supply security as well as to economic, environmental and regional development issues. Taking into account the available economic potential of RES, this would lead to increased utilisation of solid biomass (mainly wood) as well as biogas, wind energy and hydropower [4]. In order to achieve the RES target, it is planned to increase the use of these resources for the electricity production (from $44.9 \%$ in 2005 to $59.8 \%$ in 2020), heating (from $42.7 \%$ in 2005 to $53.4 \%$ in 2020) and transport (from $0.9 \%$ in 2005 to $10 \%$ in 2020). The total expected amount of energy generated from RES in line with the 2020 target will constitute 80.3 PJ. The 2020 indicative target requires a significant increase in the district heat supply produced by utilising biomass ( 2.5 times, reaching $10.8 \mathrm{PJ})$. Regarding the electricity production from solid biomass, a substantial growth is expected - up to 642 GWh by 2020, and for this purpose new solid biomass CHP utilities of at least $105 \mathrm{MW}_{\mathrm{el}}$ total capacity will be set up.

\section{METHODOLOGY OF THE ASSESSMENT}

To estimate the heat and electricity production from wood biomass both in terms of the economic feasibility and the competitiveness of different fuel types taking into account the conditions of electricity market the following tasks have been fulfilled:

1. Based on the cost analysis and using data from the projects implemented in Latvia as well as international literature data, the energy production price calculation has been done for a BH and a CHP plant; a relevant model has also been created.

2. The price has been set for the electricity produced by a CHP plant at which its operation is economically justified (taking into account the existing and future support instruments).

The economic feasibility of biomass use at a $\mathrm{BH}$ was analysed taking into account current competition on the fuel market in Latvia, where the dominant type of fuel for DHS is natural gas. The following basic assumptions regarding the model input data have been used:

- BH installed capacity is in the range from 0.1 to $50 \mathrm{MW}$;

- BH installed capacity corresponds to the heat load of consumers connected to the DHS;

- heat energy production efficiency of a natural gas fuelled BH is assumed to be $92 \%$, while that of a $\mathrm{BH}$ operating on wood biomass $-80 \%$;

- differentiated end tariffs in the sale of natural gas are applied depending on its annual consumption [5]; the model employs an appropriate group of natural gas consumers corresponding to the modelled heat production volume*;

- basic calculations have been done for the natural gas purchase prices of 115 and $235 \mathrm{LVL} / 1000 \mathrm{~m}^{3}$, corresponding to the minimum and maximum price

\footnotetext{
* The end tariff in natural gas sale is based: on the purchase price of natural gas on the state frontiers (which is transformed without any changes to the end tariff) and on the cost of services related to the natural gas delivery to users - transmission, storage, differentiated distribution and sales (see also Table 1 of [6]).
} 
in Latvia during the period from 1 October 2008 to 1 November 2011. The highest price of natural gas was recorded in October 2008, whereas the lowest - in the period from November 2009 to March 2010;

- the wood fuel price is determined based on the average local prices in Latvia (11.7 LVL/MWh approximately);

- the energy price consists of the following components: fuel cost, operating cost, and investment cost;

- the investment cost component includes the value of equipment (assumed to be depreciated in 10 years) with the internal return rate being 9\%;

- the operating cost component includes costs associated with the operation of a plant: salaries, social tax, materials, repairs, raw materials (water, chemicals, etc.) and other costs (various fees, communication and transportation costs, etc.). Operating costs are expressed as a functional dependence of the investment costs.

The model creation process uses information on the actual investment and operating costs in Latvia for the last three years, see Table 1. Investments are modelled in view of the $\mathrm{BH}$ re-construction, thus they comprise only a fraction of the investments that would be required for the construction of a new $\mathrm{BH}$.

Table 1

Technical and financial data for biomass boiler houses

\begin{tabular}{|l|l|c|c|c|c|c|c|}
\hline $\begin{array}{l}\text { Installed heat capacity, } \\
\mathrm{MW}_{\text {th }}\end{array}$ & 0.5 & 1 & 4 & 10 & 16 & 30 & 50 \\
\hline $\begin{array}{l}\text { Specific investments, thousand } \\
\text { LVL/MW }\end{array}$ & 88.8 & 84.0 & 75.2 & 69.9 & 67.3 & 64.0 & 61.4 \\
\hline $\begin{array}{l}\text { Fixed operational costs, } \\
\text { LVL/MWh }\end{array}$ & 7.1 & 6.7 & 6.0 & 5.6 & 5.4 & 5.1 & 4.9 \\
\hline
\end{tabular}

The use of CHP technologies implies that both the products - electricity and heat - have to be sold to consumers. The corresponding analysis was carried out based on the competitive price of heat for DHS and the electricity price at the Nordic Electricity Market (Nord Pool). It is assumed that the heat sale price at the border between the CHP utility and the DH transmission network is equal to the heat sale price at the corresponding BH capacity. The remaining costs are allocated to electricity production. The fuel price for a CHP plant is assumed to be equal to that for a $\mathrm{BH}$. The model uses the technical and financial data for steam turbines and Organic Ranking Cycle (ORC) technology (Table 2). The investments include the total costs of a CHP plant's construction. When modelling the electricity price, the number of CHP unit operation hours is of great importance. In the model, the basic operational conditions - for the heating load and the hot water load - are analysed.

The steam turbine technology is suitable for consumers with a constant heat load of at least 5-8 $\mathrm{MW}_{\text {th }}$, because its main disadvantages are rather a low electricity/heat ratio (i.e. a small amount of electricity produced) and high specific investment costs, especially for capacities up to $10 \mathrm{MW}_{\mathrm{el}}$. The application of steam turbine technology is limited in Latvia due to small heat loads, especially during summer, because the consumers are mostly households, the service sector and 
public institutions; thus the optimum operation of steam turbines can be provided only by the major DHSs.

For minor heat loads (i.e. for the installed CHP capacity of $0.3-2 \mathrm{MW}_{\mathrm{el}}$ ) more suitable is the ORC technology, for which the electricity/heat ratio is in the range of 0.2-0.22 [7]. Since the construction of the first wood-fuelled ORC CHP plant (in the $2^{\text {nd }}$ half of the 90-ies) a sufficiently large number of CHP units have been built; hence, the technology is improved and can be considered available for the commercial use.

Table 2

Average key figures for the biomass CHP technologies

\begin{tabular}{|l|c|c|c|c|c|c|c|c|c|}
\hline Technology & \multicolumn{7}{c|}{$\begin{array}{c}\text { Solid biomass CHP } \\
\text { (steam turbine) }\end{array}$} & \multicolumn{3}{c|}{$\begin{array}{c}\text { Solid biomass CHP } \\
\text { (ORC) }\end{array}$} \\
\hline \multicolumn{8}{|c|}{ Technical data } \\
\hline Installed capacity, MW $\mathrm{el}_{\mathrm{l}}$ & 0.5 & 1 & 4 & 10 & 20 & 0.5 & 1.1 & 2 \\
\hline Electricity/heat ratio & 0.12 & 0.15 & 0.22 & 0.33 & 0.40 & 0.21 & 0.21 & 0.21 \\
\hline \multicolumn{8}{|c|}{ Financial data } \\
\hline $\begin{array}{l}\text { Specific investments, } \\
\text { mill. LVL/MW }\end{array}$ & 5.6 & 4.8 & 3.5 & 3.2 & 3.1 & 6.7 & 4.1 & 3.2 \\
\hline $\begin{array}{l}\text { Fixed operational costs } \\
\text { (thousand LVL/MW/year) }\end{array}$ & 384 & 270 & 156 & 121 & 108 & 384 & 270 & 156 \\
\hline
\end{tabular}

The CHP based on biomass gasification is not used in the modelling, since the corresponding technologies are still in the development and optimisation stage. Although the process is well studied, the main obstacles to rapid penetration of such a technology are high requirements to the quality of fuels, the by-product generation, and the process instability.

\section{RESULTS AND DISCUSSION}

The results obtained clearly indicate that the price of heat produced at a wood-fuelled $\mathrm{BH}$ is competitive with that for heat produced at the natural gas $\mathrm{BH}$, see Fig. 3. Even at the lowest purchase price of natural gas, the price of the heat energy produced at a wood-fuelled $\mathrm{BH}$ is just about average 10-15\% higher than for the natural gas $\mathrm{BH}$, while at higher gas prices the former is $24-28 \%$ lower on the average.

The price of heat energy produced at a natural gas fuelled $\mathrm{BH}$ is much more sensitive to the fluctuations in fuel prices. In this case, increase in the fuel price of $10 \%$ causes an $8-9 \%$ rise in the heat energy price. For the wood-fuelled $\mathrm{BH}$ this percentage is $5-6 \%$, which is explained by differences in the structure of heat energy price (see Fig. 4).

The competitiveness of wood biomass for heat production is also confirmed by the operation of existing BHs. According to the Latvia's District Heating Association and the Public Utilities Commission information, the price for consumers (including production, transmission and distribution costs) of the heat produced at a biomass-fuelled BH in 2010 was on the average about 5-13\% lower than that of heat produced at a BH fuelled by natural gas (with its purchase price of $170 \mathrm{LVL} /$ thousand $\mathrm{m}^{3}$ ). 


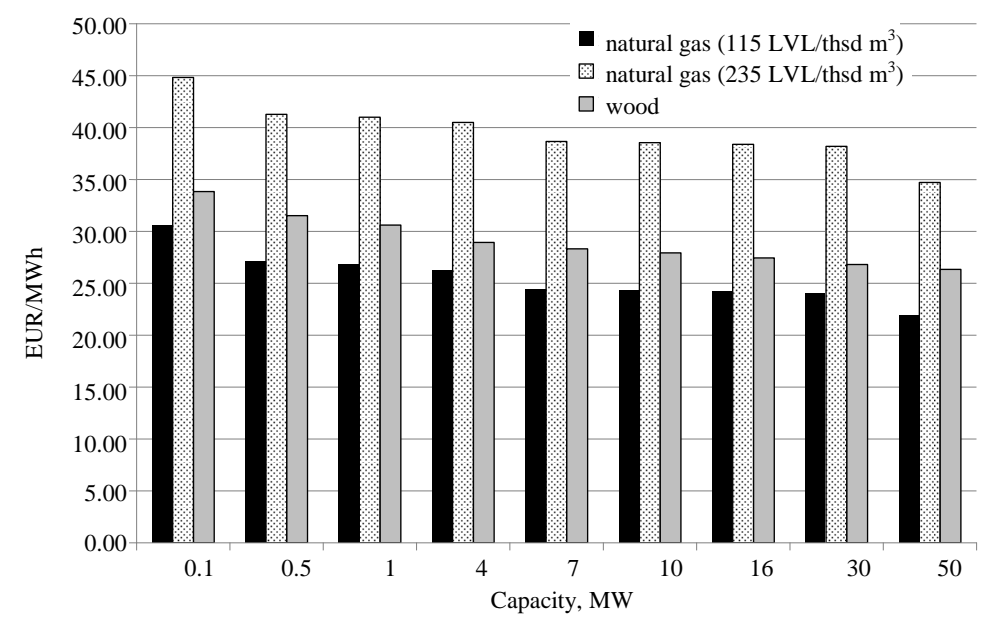

Fig. 3. Prices of heat produced by natural gas- and wood-fuelled BHs.

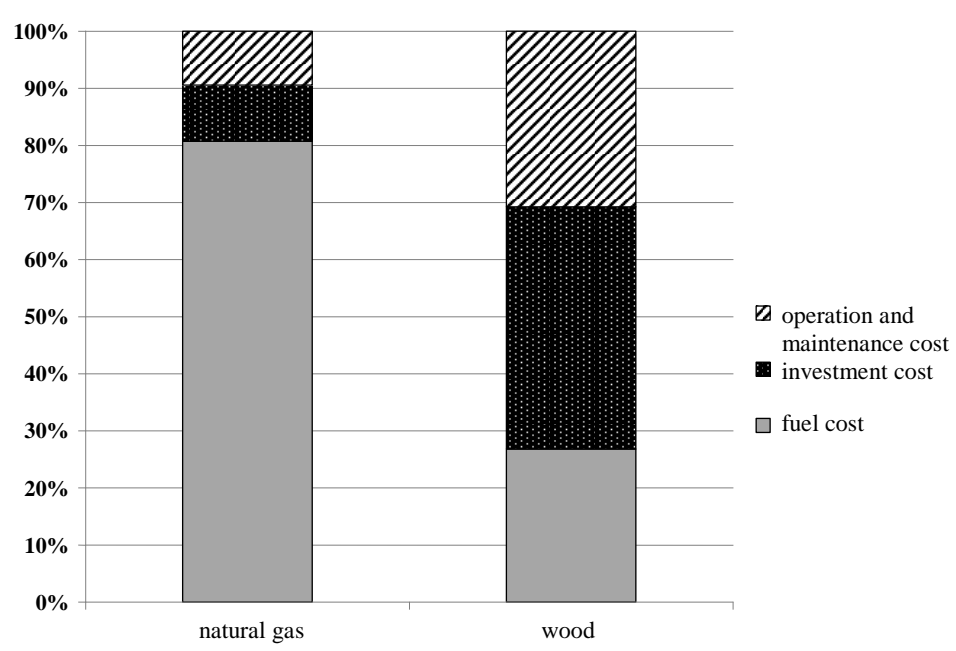

Fig. 4. The heat price structure for natural gas- and wood-fuelled BHs.

The results of CHP plant modelling show a significant impact on the electricity production price of two main parameters - installed electrical capacity and plant operating hours per year (see Fig. 5). In Latvia, which is typically characterised by a DHS consumer structure without industrial enterprises and, consequently, without large heat loads (especially in summer), this leads to significantly limited competitiveness of biomass CHP. Namely, in order to increase the price competitiveness for electricity produced at a biomass CHP plant, the largest possible number of operating hours should be achieved (approaching the base load power station). At the existing DHS consumer structure in Latvia, this means that the nominal heat output of such a CHP plant is equal to the average heating load for hot water preparation in summer. However, the DHS hot water heating load of Latvian towns - as a rule - is limited; therefore, in these cases only a CHP plant with a low electrical capacity could be considered. Consequently, electricity production costs for small-scale CHP plants remain high due to high investment costs per installed capacity unit. 


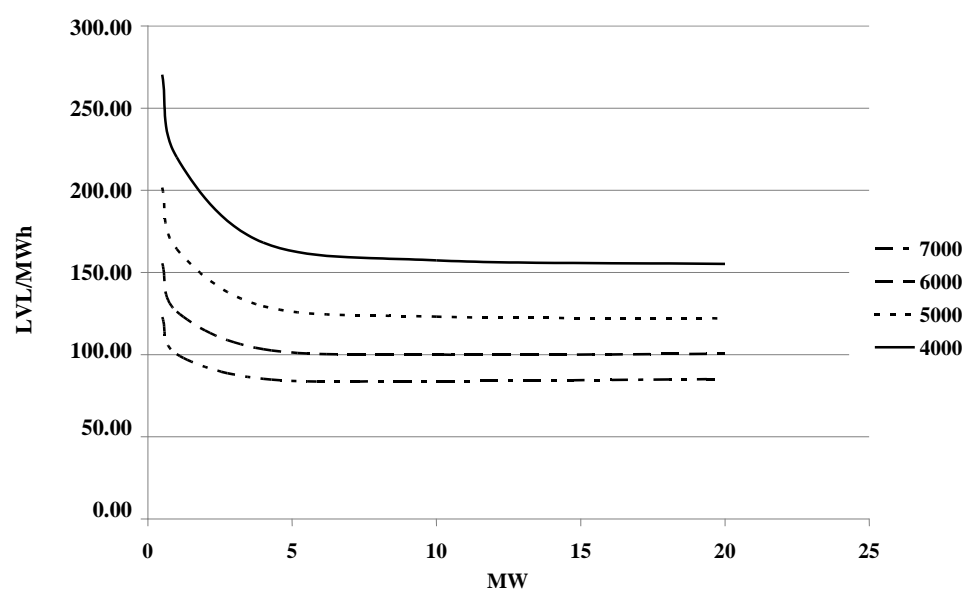

Fig. 5. Electricity price for biomass CHP plants with different number of annual operation hours $v s$. a plant's capacity.

Promotion of the electricity market in the Baltic States with its further integration into the Nordic electricity market is one of the main challenges that will determine the development of electricity sector. On June 17, 2009, the leaders of the Baltic Sea countries (Denmark, Sweden, Finland, Germany, Poland, Lithuania, Latvia, and Estonia) and President of the European Commission signed the Memorandum on the implementation of the Baltic Energy Market Interconnection Plan (BEMIP), which provides that by the indicative 2015 the Baltic States shall introduce the Nordic electricity market model which will operate on the Nord Pool business principles. Taking into account the electricity market development trends, in this study the Nord Pool average price was used as the reference electricity price. During the period from 2000 to 2011 the Nord Pool price dynamics can be characterised by both "highs" and "lows" (see Fig. 6), but overall there was a price increase from $15 \mathrm{EUR} / \mathrm{MWh}$ to $60 \mathrm{EUR} / \mathrm{MWh}$. In 2011, the average electricity price at the Nord Pool was 52 EUR/MWh or $\sim 36.5$ LVL/MWh.

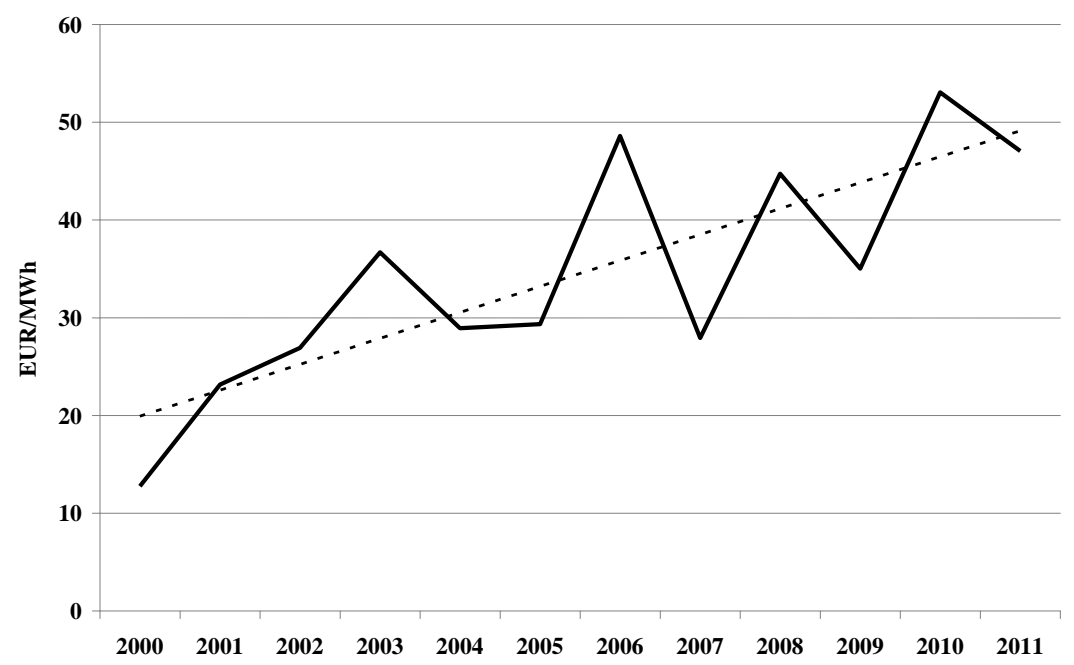

Fig. 6. Nord Pool electricity price dynamics [8]. 
Figures 5 and 6 show that the calculated price of electricity providing economic viability of a wood biomass CHP utility is significantly higher than the Nord Pool price. Thus it is necessary to apply a support mechanism to facilitate the introduction of biomass CHP technologies into the market. The authors have evaluated the impact of two different support instruments on the biomass CHP viability. In the first case, it is assumed that the CHP plant sells electricity at the market prices (Nord Pool), therefore investment subsidies are the only support instrument. As shown in Table 3, the required investment support intensity depends on the number of operating hours and the installed capacity of a CHP plant (the lower value of the tabulated intervals corresponds to plants with the installed capacity exceeding $5 \mathrm{MW}_{\mathrm{el}}$ ), but in all cases the need for investments is high.

\section{Table 3}

Required investment support intensity depending on the wood biomass CHP plant's operating hours

\begin{tabular}{|c|c|}
\hline Operating hours & Required intensity of investment aid, \% \\
\hline 7000 & $40-50$ \\
\hline 6000 & $50-60$ \\
\hline 5000 & $60-70$ \\
\hline 4000 & $70-80$ \\
\hline
\end{tabular}

Another widely applied tool for the CHP support is the feed-in tariff. In Latvia, the electricity produced in CHP plants using RES is subjected to the mandatory procurement [9]. The feed-in tariff on the electricity produced in a small-scale (up to $4 \mathrm{MW}_{\mathrm{el}}$ ) wood biomass CHP plant is directly proportional both to the end tariff of natural gas sale and the price differentiation coefficient depending on the electric capacity of the CHP plant [6]. Over the last three years the mandatory procurement price has fluctuated in the range from 65 to $145 \mathrm{EUR} / \mathrm{MWh}$, thus the feed-in tariff instability due to the natural gas price fluctuations turned out to be one of the main disadvantages of the current support mechanism, which leads to highly uncertain situations for potential investors of the project. Biomass CHP development practices in Latvia have shown that the current feed-in tariff itself is not incentive enough, and the active introduction of biomass CHP technologies started only when to the feed-in tariff mechanism the investment support from the EU Cohesion Fund [10] was added, and when the Climate Change Financial Instrument (the state budget programme financed from the sale of stateowned assigned amount units $-\mathrm{CO}_{2}$ emissions - under procedures pursuant to Article 17 of Kyoto protocol) became available [11].

According to the draft law on the Renewable Energy [12], the electricity producers selling the RES electricity at a market price would gain a feed-in premium. In compliance with the mentioned draft law, this premium is composed of the GHG emission component, the capacity component (available in the case it provides the installed electrical capacity operation of at least $3500 \mathrm{~h} / \mathrm{year}$ ), and the agricultural component (available only if the by-products of animal origin account for at least $70 \%$ of the raw materials consumed in the fermentation process 
for biogas production). The feed-in premium payments referred to in the draft law until December 31, 2015 are the fixed values, namely: capacity component $32.9 \mathrm{LVL} / \mathrm{MWh}$, GHG component - $17.4 \mathrm{LVL} / \mathrm{MWh}$, and the agricultural component $-14.9 \mathrm{LVL} / \mathrm{MWh}$. One can see that if the electricity market price is 36.5 LVL/MWh (52€/kWh), the electricity producer who uses wood biomass in CHP would receive up to $86.8 \mathrm{LVL} / \mathrm{MWh}$ for the electricity produced. As compared with the modelling results presented in Fig. 5, it can be seen that such payment would ensure only a minimum of wood biomass CHP viability only at the electric capacity and the number of operating hours being relatively large $\left(\sim 5 \mathrm{MW}_{\mathrm{el}}\right.$ and $\sim 7000 \mathrm{~h} /$ year, respectively), while the viability of a small-scale wood biomass CHP plant could be achieved only through adjustment of the support mechanism depending on the installed electrical capacity.

\section{CONCLUSIONS}

The modelling results show that the production of heat by wood-fuelled BHs is competitive with its production at BHs fuelled by natural gas or other fossil fuels. In this situation, in order to promote a wider use of wood biomass in $\mathrm{DH}$ systems, the state support should be established as an environmental investment to help covering the extra costs compared with the conventional BHs (in accordance with the EC Regulation 800/2008).

Meanwhile, the proposed so far single support instruments for electricity production at wood-fuelled CHP plants do not provide their economic feasibility and wide-scale entering of these technologies in the market. In order to ensure the viability of the wood-fuelled CHP, joint support instruments are currently used the regional investment aid, the climate change financial instrument, and the feedin payments. However, combination of such different support instruments sometimes leads to creation of unequal competition on the RES electricity market due to different support intensity for the CHP plants put into operation in the same year.

In terms of biomass CHP development and the intensity of the applied support instruments, a compromise should be found between the economy-dictated demand for developing the projects with a CHP capacity greater than $5 \mathrm{MW}_{\mathrm{el}}$ and the actual low heat loads for the potential users of biomass energy in many towns and villages of Latvia.

The results obtained in the comparative analysis of the biomass fuel utilisation by $\mathrm{BH}$ and CHP plants allow for the conclusion that at the current degree of technological development the priority direction of the Latvian energy policy (up to 2020) should be the biomass utilisation for heat production by boiler houses as compared with its utilisation for this purpose by CHP plants.

\section{ACKNOWLEDGEMENT}

This work has been supported by the National Research Programme 20102013 "Technologies for Innovative Production and Use of Energy Resources and Provision of Low Carbon Emissions by Means of Renewable Energy Sources, Support Measures for the Mitigation of Environment and Climate Degradation LATENERGI" 


\title{
REFERENCES
}

1. Europe 2020 targets: national targets http://ec.europa.eu/europe2020/pdf/targets_en.pdf

2. Statistics Databases: Energy Central Statistical Bureau of Republic of Latvia http://data.csb.gov.lv/DATABASEEN/vide/Annual\%20statistical\%20data/Energy/Ener gy.asp

3. Share of renewable energy in gross final energy consumption Eurostat. http://epp.eurostat.ec.europa.eu/portal/page/portal/energy/data/main-tables, see Energy Statistics - quantities, table tsdcc110

4. Information Report: Republic of Latvia National Renewable Energy Action Plan for implementing Directive 2009/28/EC of the European Parliament and of the Council, of 23 April 2009 on promoting the use of energy from renewable sources and amending and subsequently repealing Directives 2001/77/EC and 2003/30/EC by 2020 http://ec.europa.eu/energy/renewables/transparency_platform/doc/national_renewable_ energy_action_plan_latvia_en.pdf

5. Decision No.247 of the Public Utilities Commission (2008, in Latvian). http://www.sprk.gov.lv/doc_upl/Lemums247D24072008.doc

6. Klāvs, G., Kudreņickis I., \& Kundziņa, A. (2009). Feed-in tariffs and competitiveness of small scale wood fuel CHP plants in Latvia. Latv. J. Phys. Tech. Sci. (5), 24-34.

7. Duvia, A., Gaia, M. (2002). ORC plants for power production from biomass from $0.4 \mathrm{MW}_{\text {el }}$ to $15 \mathrm{MW}$ el: Technology, efficiency, practical experiences and economy. Presented at: the $7^{\text {th }}$ Holzenergie - Symposium, October 2002, ETH Zürich (Switzerland).

8. www.nordpool.fi

9. Regulations No 221. Regarding Electricity Production and Price Determination upon Production of Electricity in Cogeneration (adopted 10.03.2009, last amendments 07.09.2010). Cabinet of Ministers of Republic of Latvia.

http://www.vvc.gov.lv/export/sites/default/docs/LRTA/MK_Noteikumi/

10. Atjaunojamos energoresursus izmantojošu koǵenerācijas elektrostaciju attīstība: noslēgtie līgumi (Development of RES utilizing CHP: signed contracts, in Latvian) Investment and Development Agency of Latvia.

http://www.liaa.lv/lv/es_fondi/es_fondi/noslegtie_ligumi_20072013plano/_gv/groupid_1488/.

11. Klimata pārmaiņu finanšu instruments: Atjaunojamo energoresursu izmantošana siltumnīcefekta gāzu emisiju samazināšanai (Climate Change Financial Instrument: Utilisation of RES for GHG emissions reduction, in Latvian). Ministry of Environmental Protection and Regional Development, open tender website http://www.varam.gov.lv/lat/darbibas_veidi/KPFI/projekti/?doc=11391.

12. Atjaunojamās enerğijas likumprojekts (Renewable Energy Law, draft, in Latvian). http://titania.saeima.lv/LIVS11/saeimalivs11.nsf/0/529F4C8FD452DF5EC2257950003 A82C5?OpenDocument.

\section{SILTUMENERĢIJAS UN ELEKTROENERĢIJAS RAŽOŠANAS LATVIJĀ, IZMANTOJOT KOKSNES BIOMASU, KONKURĒTSPĒJAS UN ATBALSTA VEIDU SALİDZINOŠ $\bar{A}$ ANALĪZE}

\author{
G. Klāvs, I. Kudreņickis, A. Kundziņa \\ Kopsavilkums
}

Atjaunojamo enerğijas resursu izmantošana ir viens no principiālajiem attīstības virzieniem siltumnīcefekta gāzu emisiju ierobežošanai un energoapgādes 
drošuma paaugstināšanai Latvijā. Līdz šim koksnes kurināmā izmantošanai Latvijas centralizētās siltumapgādes sistēmās kopumā ir pakārtota vieta, dominējot dabasgāzei. Būtisks uzdevums ir novērtêt siltumenerğijas un elektroenerğijas ražošanas, izmantojot koksnes biomasu, ekonomisko pamatojumu un konkurētspēju primāro enerğijas resursu konkurences un elektroenerǵijas tirgus apstākḷ̆os. Balstoties uz izveidoto izmaksu modeli, autori rakstā novērtē katlu mājās un koǵenerācijas stacijās saražotās siltumenerǵijas un elektroenerǵijas ražošanas cenas un analizē to konkurētspēju, salīdzinot ar attiecīgi dabasgāzi izmantojošas katlu mājas siltumenerğijas cenu un NordPool biržas cenu, kas tiek izmantota kā elektroenerǵijas tirgus atsauces cena. Pētījuma rezultāti parāda, ka koksnes kurināmā izmantošana katlu mājās siltumenerǵijas ražošanai ir konkurētspējīga. Savukārt attiecībā uz koǵenerācijas stacijām autori novērtē nepieciešamo atbalsta intensitāti starpības segšanai starp elektroenerğijas ražošanas cenu un NordPool cenu, diviem plašāk izmantotiem atbalsta instrumentiem - investīciju atbalsts un obligātā iepirkuma cena. Salīdzinošā pētījumā iegūtie rezultāti par biomasas kurināmā izmantošanu katlu mājās un kog̣enerācijas stacijās l̦auj secināt, ka pie esošās tehnologiju attīstības pakāpes, Latvijas enerḡetikas politikā līdz 2020. gadam biomasas izmantošanai katlu mājās siltumenerǵijas ražošanai ir jāuzskata par prioritāru, salīdzinot ar biomasas izmantošanu koǵenerācijas iekārtās.

14.03.2012. 